\title{
PENERAPAN PERMAINAN MONOPOLI DIGITAL UNTUK MENINGKATAN MINAT BELAJAR SISWA SD PADA MATERI OPERASI HITUNG BILANGAN CACAH
}

\author{
Ria Widiyanti ${ }^{1}$, Farida Ulfa $^{2}$ \\ $\left({ }^{1,2}\right.$ Guru Matematika SD Islam Sabilillah Malang) \\ E-mail: ${ }^{1}$ rianabilalaila@gmail.com
}

\begin{abstract}
Abstrak
Penelitian ini bertujuan untuk mendiskripsikan penerapan permainan monopoli digital untuk meningkatkan minat belajar siswa pada materi operasi hitung bilangan cacah kelas IIIA SD Islam Sabilillah Malang tahun pelajaran 2018/2019. Pendekatan yang digunakan dalam penelitian ini adalah pendekatan kualitatif, sedangkan jenis penelitian yang digunakan adalah penelitian tindakan kelas (PTK). Subjek penelitian ini adalah siswa kelas IIIA SD Islam Sabilillah Malang yang berjumlah 32 siswa. Teknik pengumpulan data yang digunakan dalam penelitian ini antara lain: (1) observasi, (2) catatan lapangan, (3) wawancara, dan (4) tes. Data yang digunakan adalah data kualitatif dan data kuantitatif. Data kualitatif berupa data observasi, hasil wawancara dan hasil catatan lapangan. Sedangkan data kuantitatif berupa hasil tes akhir siklus. Hasil penelitian menunjukkan bahwa penggunaan permainan monopoli digital dapat meningkatkan minat belajar matematika siswa kelas III A di SD Islam Sabilillah Malang. Hal tersebut dapat dilihat dari data penelitian yang menunjukkan bahwa Skor rata-rata angket minat belajar matematika siswa sebelum diberi tindakan hanya sebesar 30,39 dan presentase siswa yang telah mencapai skor minat sedang hanya sebesar 38\%, setelah dikenai tindakan pada siklus 2 skor rata-rata angket meningkat menjadi 40,13 dengan presentase $81 \%$, sehingga peningkatannya sebesar $43 \%$; (2) persentase hasil pengamatan aktivitas guru sebesar 77,2\% pada siklus I meningkat menjadi $82 \%$ pada siklus II dengan peningkatan sebesar $4,8 \%$; (3) persentase hasil pengamatan aktivitas siswa sebesar $78,8 \%$ pada siklus I meningkat menjadi $90 \%$ pada siklus II dengan peningkatan sebesar $11,2 \%$; (4) Rata-rata nilai tes akhir sebesar 75,16 pada siklus 1 meningkat menjadi 87 pada siklus 2 dan presentase ketuntasan siswa sebesar $55 \%$ pada siklus 1 meningkat menjadi $87 \%$ pada siklus 2 . Rekomendasi untuk penelitian selanjutnya adalah untuk mengembangkan multimedia monopoli digital ini agar lebih interaktif atau skenario permainan yang lebih menarik.
\end{abstract}

Kata Kunci: minat, monopoli digital, sekolah dasar, operasi bilangan cacah.

\begin{abstract}
This study aims to describe the application of digital monopoly games to increase students' interest in learning in the count material operating in class IIIA Sabilillah Islamic Elementary School in the academic year 2018/2019. The approach used in this study is a qualitative approach, while the type of research used is classroom action research (CAR). The subjects of this study were class IIIA students at SD Islam Sabilillah Malang, totaling 32 students. Data collection techniques used in this study include: (1) observation, (2) field notes, (3) interviews, and (4) tests. The data used are qualitative data and quantitative data. Qualitative data in the form of observation data, interview results and field notes. While quantitative data in the form of the final cycle test results. The results showed that the use of digital monopoly games could increase the interest in learning mathematics in grade III A students at Sabilillah Islamic Elementary School Malang. This can be seen from the research data which shows that the average score of students' mathematics learning interest questionnaire before being given an action is only 30.39 and the percentage of students who have achieved a moderate interest score is only $38 \%$, after being subjected to action on cycle 2 the average score the average questionnaire increased to 40.13 with a percentage of $81 \%$, so the increase was $43 \%$; (2) the percentage of the results of observations of teacher activities by $77.2 \%$ in the first cycle increased to $82 \%$ in the second cycle with an increase of $4.8 \%$; (3) the percentage of observations of student activities at $78.8 \%$ in the first cycle increased to $90 \%$ in the second cycle with an increase of $11.2 \%$;
\end{abstract}


(4) The average final test score of 75.16 in cycle 1 increased to 87 in cycle 2 and the percentage of student completeness by $55 \%$ in cycle 1 increased to $87 \%$ in cycle 2 . The recommendation for further research was to develop multimedia digital monopoly this is to make it more interactive or a more interesting game scenario.

Keywords: interest, digital monopoly, elementary school, enumeration operations.

\section{PENDAHULUAN}

Keberhasilan pembelajaran ditandai dengan perolehan pengetahuan keterampilan dan sikap positif pada diri individu, sesuai dengan tujuan yang diharapkan. Keberhasilan belajar ini sangat dipengaruhi oleh banyak faktor, dan salah satunya adalah profesionalisme guru dalam memanfaatkan teknologi untuk mengembangkan media pembelajaran, karena guru adalah aktor utama dalam proses pembelajaran (Hasana \& Maharany, 2017). Dalam proses pembelajaran terdapat sistem yang harus diperhatikan dengan baik. Pembelajaran dikatakan sebagai sistem karena di dalamnya memiliki komponen-komponen yang saling berkaitan dalam rangka mencapai tujuan yang telah ditentukan. Komponen tersebut terdiri atas tujuan, materi, metode, media, dan evaluasi. Masing-masing komponen tersebut saling berkaitan dan merupakan satu kesatuan yang tidak terpisahkan.

Pesatnya laju perkembangan teknologi dan informasi diharapkan mampu meningkatkan mutu kualitas pembelajaran (Nursit, 2016). Hal ini bertujuan untuk meningkatkan pemahaman siswa terhadap materi pelajaran yang ditunjukkan dengan peningkatan hasil belajar siswa. Diantara komponen pembelajaran sebagai sistem, penggunaan media pembelajaran menjadi perhatian khusus di kalangan Guru dan Siswa. Guru harus menggunakan media terbaik untuk memfasilitasi pembelajaran, salah satunya adalah media pembelajaran berbasis digital, sebab hal ini dapat menarik minat siswa untuk belajar. Kebiasaan siswa bermain game dan melihat hiburan pada perangkat digitalnya (smartphone, personal computer, maupun laptop) akan tergeser secara halus dengan kebiasaan belajar dengan menggunakan perangkat yang sama. Minat dapat mempengaruhi kualitas pencapaian hasil belajar siswa dalam bidang studi tertentu. Seorang siswa yang menaruh minat besar terhadap matematika akan memusatkan perhatiannya lebih banyak daripada siswa lain. Kemudian karena pemusatan perhatian yang intensif terhadap materi itulah yang memungkinkan siswa tersebut untuk belajar lebih giat dan akhirnya mencapai hasil belajar yang diinginkan (Syah, 2010). Untuk itu, dibutuhkan suatu kegiatan yang dilakukan oleh guru dalam upaya membangkitkan minat belajar siswa. Minat tidak hanya menjadikan siswa terlibat dalam kegiatan akademik, minat juga penting dalam menentukan seberapa jauh siswa belajar dari suatu kegiatan pembelajaran atau seberapa jauh menyerap informasi yang disajikan kepada mereka. Siswa yang berminat untuk belajar sesuatu akan menggunakan proses kognitif yang lebih tinggi dalam mempelajari materi itu. Misalnya siswa memiliki minat untuk memecahkan masalah, bertanya pada guru atau teman terhadap materi yang belum dikuasai, berani berargumentasi sebagai bentuk komunikasi dan interaksi positif, serta minat lain yang mendukungnya untuk memahami materi.

Berdasarkan hasil observasi yang dilakukan di kelas IIIA SD Islam Sabilillah Malang khususnya dalam mata pelajaran Matematika, minat belajar siswa masih rendah. Mayoritas siswa kurang memiliki minat belajar yang tinggi dalam mata pelajaran Matematika. Indikator aktivitas siswa ketika pembelajaran yang menggambarkan minat belajar siswa masih rendah antara lain siswa kurang tekun mengerjakan tugas yang diberikan guru, mudah putus asa dalam menghadapi kesulitan belajar/soal-soal, kurangnya motivasi dalam mencari dan memecahkan soal-soal, serta kurangnya motivasi dalam belajar seperti berbicara ketika guru menjelaskan, terlalu lama dalam mengerjakan soal latihan, sebagian besar kurang aktif bertanya tentang materi pelajaran, dan siswa kurang memahami materi yang diberikan. Siswa 
tampak kurang antusias ketika mengerjakan soal, tidak mau bertanya pada teman atau guru jika tidak bisa, dan nilai tes tentang materi operasi hitung bilangan cacah yang rendah. Hal ini ditunjukkan dengan nilai rata-rata tes siswa kelas III A terkait materi operasi bilangan cacah khususnya pokok bahasan menentukan pasangan bilangan yang hasil jumlah, selisih, hasil kali, dan hasil baginya diketahui yaitu 60, yang berada di bawah nilai KKM yang ditetapkan yaitu 75. Hal ini disebabkan karena adanya keterkaitan antara minat dan hasil belajar. Syah (2010) menyatakan bahwa minat dapat mempengaruhi kualitas pencapaian hasil belajar siswa dalam bidang studi tertentu.

Menurut Pitadjeng (2006), salah satu pembelajaran yang dapat meningkatkan minat belajar siswa adalah pembelajaran dengan permainan. Pitadjeng berpendapat bahwa "Permainan interaktif merupakan permainan yang dikemas dalam pembelajaran, sehingga anak didik menjadi aktif dan senang dalam belajar". Rasa senang ini nanti dapat berdampak terhadap minat belajar siswa terhadap mata pelajaran matematika dan hasil belajar siswa. Hurlock (1980) juga memberikan pendapatnya bahwa akhir masa kanak-kanak yaitu mulai umur 6 tahun sampai mengalami pubertas sering disebut sebagai usia bermain, disebut demikian bukan karena banyaknya waktu bermain melainkan luasnya minat dan kegiatan bermain. Dari sekian banyak permainan yang dikembangkan untuk pembelajaran, Susanto dkk (Susanto dkk, 2012) menyatakan bahwa Pembelajaran dengan menggunakan media pembelajaran monopoli lebih efektif dibandingkan dengan metode pembelajaran konvensional. Husna (Husna, 2016) mengatakan bahwa monopoli adalah salah satu permainan papan yang paling terkenal di dunia. Karena dengan media monopoli siswa menjadi lebih aktif lagi dalam proses pembelajaran, selain itu pembelajaran yang awalnya berpusat pada guru dengan penggunaan media pembelajaran monopoli pembelajaran berpusat pada siswa. Pada permainan monopoli siswa dituntut untuk menguasai materi dengan cara yang menyenangkan, sehingga akan tumbuh minat belajar siswa. Hal ini sejalan dengan Sadiman dkk (Sadiman dkk, 2011) yang menyatakan bahwa penggunaan media pembelajaran permainan seperti monopoli fisika memiliki beberapa keunggulan dibandingkan media pembelajaran yang lain, yaitu (1) permainan adalah sesuatu yang menyenangkan untuk dilakukan, sesuatu yang menghibur, (2) permainan memungkinkan adanya partisipasi aktif dari siswa untuk belajar, (3) permainan dapat memberikan umpan balik langsung, (4) permainan memungkinkan penerapan konsep-konsep ataupun peran-peran ke dalam situasi dan peranan yang sebenarnya di masyarakat, (5) permainan bersifat luwes, (6) permainan dapat dengan mudah dibuat dan diperbanyak.

Berdasarkan hal tersebut maka perlu dikembangkan suatu media pembelajaran baru yang memiliki konsep belajar sambil bermain dimana permainan tersebut dapat dimainkan secara digital agar minat siswa dalam belajar matematika dapat meningkat. Media ini disetting dan dimanipulasi oleh guru sehingga siswa akan lebih banyak beraktivitas sehingga diharapkan akan meningkatkan minat belajar siswa.

\section{METODE}

Pendekatan yang digunakan dalam penelitian ini adalah kualitatif dan kuantitatif, sedangkan jenis penelitiannya adalah penelitian tindakan kelas (classroom action research). Penelitian ini dilaksanakan di SD Islam Sabilillah Malang, Jalan. Ahmad Yani No. 15 Kota Malang. Subjek dalam penelitian ini adalah siswa kelas IIIA yang terdiri dari 31 siswa semester Gasal tahun ajaran 2018/2019. Penelitian dilaksanakan dalam 2 siklus. Siklus I terdiri dari 3 pertemuan. Siklus II juga terdiri dari 2 pertemuan. Sebelum tindakan siklus, peneliti melakukan tindkan pra siklus yang terdiri dari penyebaran angket minat belajar siswa dan test pra siklus untuk mengetahui kemampuan awal siswa. Alur siklus yang digunakan dalam penelitian adalah alur siklus model Kemmis dan Taggart yang terdiri dari perencanaan, pelaksanaan tindakan dan observasi serta refleksi. 
Adapun teknik pengumpulan data dalam penelitian ini dilakukan dengan : (1) wawancara, digunakan untuk mendapatkan informasi lebih mendalam tentang keadaan kelas tersebut yang dilakukan sebelum penelitian, (2) observasi, digunakan untuk mengamati aktivitas guru dan siswa selama proses pembelajaran berlangsung, (3) catatan lapangan, digunakan untuk melengkapai data yang tidak tercantum dalam lembar observasi, dan (4) angket minat belajar, digunakan untuk mengetahui minat belajar siswa.

Instrumen yang digunakan dalam penelitian ini adalah sebagai berikut: (1) pedoman wawancara, (2) lembar observasi, terdiri dari lembar observasi aktivitas guru dan lembar observasi aktivitas siswa. Observasi dilaksanakan selama proses pembelajaran berlangsung, (3) pedoman catatan lapangan, diisi oleh seorang pengamat yaitu guru mata pelajaran matematika kelas IIIA, dan (4) angket minat belajar.

Analisis data dilakukan setelah pemberian tindakan. Analisis data dalam penelitian ini terdiri dari: (1) analisis data kualitatif, yaitu: reduksi data (data reduction), penyajian data (data display), dan penarikan kesimpulan atau verifikasi (conclusion drawing/verification), dan (2) analisis data kuantitatif, dianalisis dengan menggunakan rumus persentase ketuntasan belajar dan rata-rata kelas.

\section{HASIL}

Hasil penelitian tindakan kelas tentang penerapan permainan monopoli digital untuk meningkatkan minat belajar siswa kelas IIIA SD Islam Sabilillah Malang tahun pelajaran 2018/2019 diuraikan menjadi 3 bagian, pra siklus, siklus 1, dan siklus 2sebagai berikut.

\section{Pra Siklus}

Hasil penelitian pada pada pra siklus terdiri dari hasil angket minat belajar siswa dan hasil pretes siswa. Hasil angket minat siswa ditampilkan pada tabel berikut.

Tabel 1 Persentase siswa yang sudah dan belum mencapai minat sedang pada saat Pra siklus

\begin{tabular}{lll}
\hline Keterangan & Frekuensi & Persentase \\
\hline Siswa dengan minat sedang atau lebih & 12 & $39 \%$ \\
\hline Siswa dengan minat di bawah sedang & 19 & $61 \%$ \\
\hline Skor rata-rata & 30,39 & \\
\hline
\end{tabular}

Berdasarkan tabel kriteria keberhasilan tindakan, minat belajar siswa pra PTK ini termasuk kategori sangat rendah yaitu 39\% (kurang dari 54\%). Selain itu, hasil pretest juga menunjukkan bahwa rata-rata nilai siswa yaitu 60, dengan KKM yang ditentukan yaitu 75 . Hasil pretest tersebut menunjukkan korelasi antara minat dan hasil belajar

\section{Siklus 1}

Hasil penelitian pada pada pra siklus terdiri dari hasil observasi kegiatan guru, observasi kegiatan siswa, hasil angket minat belajar siswa, dan hasil tes akhir siklus 1 siswa. Hasil angket minat siswa ditampilkan pada tabel berikut.

Tabel 2 persentase minat belajar sisiwa siklus 1

\begin{tabular}{|c|c|c|}
\hline Keterangan & Frekuensi & Persentase \\
\hline Siswa dengan minat sedang atau lebih & 21 & $68 \%$ \\
\hline Siswa dengan minat di bawah sedang & 10 & $32 \%$ \\
\hline Skor rata-rata & & \\
\hline
\end{tabular}

Data tersebut menunjukkan bahwa persentase minat siswa sedang atau lebih yaitu $68 \%$, ternyata telah mencapai tingkat sedang $(65 \%-75 \%)$ sesuai dengan tabel kriteria keberhasilan tindakan yang telah ditentukan.Pada siklus I persentase siswa yang mencapai minat sedang telah mengalami kenaikan yaitu telah mencapai $68 \%$ atau berada dalam kriteria sedang dari sebelumnya sebesar 39\% yang dalam kriteria rendah sekali. Namun skor tersebut belum mencapai kriteria keberhasilan yang telah ditentukan sebelumnya yaitu sebesar $76 \%$ 
atau mencapai kriteria tinggi. Hal ini juga didukung oleh perolehan nilai tes akhir siklus 1 yang meningkat. Pada pra siklus, nilai rata-rata siswa yaitu 60. Nilai rata-rata tes ahir pada siklus 1 yaitu 75,16. Artinya meningkat sebesar 25\%. Dengan demikian peningkatan minat belajar siswa ini sejalan dengan meningkatnya nilai rata-rata siswa sebagai hasil belajar siswa. Hasil tes akhir siklus 1 dapat dilihat pada Tabel 3 berikut.

Tabel 3 Hasil tes akhir siklus 1

\begin{tabular}{lll}
\hline No & Hasil Tes Akhir & Jumlah \\
\hline 1 & Rata-rata nilai siswa & 75,16 \\
\hline 2 & Jumlah siswa yang tuntas & 17 \\
\hline 3 & Jumlah siswa yang tidak tuntas & 14 \\
\hline & Persentase ketuntasan & $55 \%$ \\
\hline
\end{tabular}

Pada Tabel 3 terlihat bahwa rata-rata nilai siswa sudah diatas KKM yaitu diatas 75 , namun presentase ketuntasan siswa belum memenuhi kriteria yaitu diatas $80 \%$, sehingga peneliti perlu melakukan siklus berikutnya.

Dari hasil observasi kegiatan guru disimpulkan bahwa guru melakukan pembelajaran dengan cukup baik. Dari skor penilaian pembelajaran yang dilakukan guru, guru mendapat skor 70 dari skor ideal 92. Sehingga persentase kinerja guru adalah 77,2\%. Artinya guru telah mencapai $75 \%$ dalam kinerjanya mengajarkan matematika dengan menggunakan permainan monopoli. Persentase kinerja guru dalam melaksanakan pembelajaran berada pada kriteria sedang. Dari hasil observasi observasi kegiatan siswa disimpulkan bahwa siswa melakukan pembelajaran dengan cukup baik. Dari skor penilaian pembelajaran yang dilakukan siswa, siswa mendapat skor 41 dari skor ideal 52. Sehingga persentase kinerja siswa adalah 78,8\%. Artinya siswa telah mencapai $75 \%$ dalam kinerjanya melakukan pembelajaran dengan menggunakan permainan monopoli. Persentase kinerja siswa dalam melaksanakan pembelajaran berada pada kriteria sedang.

\section{Siklus 2}

Hasil penelitian pada pada pra siklus terdiri dari hasil observasi kegiatan guru, observasi kegiatan siswa, hasil angket minat belajar siswa, dan hasil tes akhir siklus 2 siswa. Hasil angket minat siswa ditampilkan pada tabel berikut.

Tabel 4 persentase minat belajar siswa siklus II

\begin{tabular}{lcc}
\multicolumn{1}{c}{ Keterangan } & Frekuensi & Persentase \\
\hline Siswa dengan minat sedang atau lebih & 25 & $81 \%$ \\
\hline Siswa dengan minat di bawah sedang & 6 & $19 \%$ \\
\hline Skor rata-rata & \multicolumn{3}{c}{40,13} \\
\hline
\end{tabular}

Pada siklus 2 persentase siswa yang mencapai minat sedang atau lebih telah mengalami kenaikan yaitu telah mencapai $81 \%$ atau berada pada kriteria tinggi dari sebelumnya sebesar $68 \%$ yang berada pada kriteria sedang. Dari data ini dapat disimpulkan bahwa tindakan yang dilakukan telah berhasil memenuhi kriteria keberhasilan tindakan sehingga penelitian dihentikan sampai dengan siklus 2. Hal ini juga didukung oleh perolehan nilai tes akhir siklus 2 yang meningkat. Pada siklus 1, nilai rata-rata siswa yaitu 75,16 . Nilai rata-rata tes akhir pada siklus 2 yaitu 87 . Artinya meningkat sebesar $16 \%$. Dengan demikian peningkatan minat belajar siswa ini sejalan dengan meningkatnya nilai rata-rata siswa sebagai hasil belajar siswa. Hasil tes akhir siklus 1 dapat dilihat pada Tabel berikut.

Tabel 5 Hasil tes akhir siklus 2

\begin{tabular}{lll}
\hline No & Hasil Tes Akhir & Jumlah \\
\hline 1 & Rata-rata nilai siswa & 87 \\
\hline 2 & Jumlah siswa yang tuntas & 27 \\
\hline 3 & $\begin{array}{l}\text { Jumlah siswa yang tidak } \\
\text { tuntas }\end{array}$ & 4 \\
\hline
\end{tabular}


Persentase ketuntasan $87 \%$

Dari Tabel terlihat bahwa nilai rata-rata siswa telah melampaui KKM, serta melampaui kriteria ketuntasan siswa diatas $80 \%$. Dari hasil observasi kegiatan guru dapat disimpulkan bahwa guru melakukan pembelajaran dengan baik. Dari skor penilaian pembelajaran yang dilakukan guru, guru mendapat skor 78 dari skor ideal 92. Artinya guru telah mencapai $82 \%$ dalam kinerjanya mengajarkan mtematika dengan menggunakan permainan monopoli digital. Selain itu, Dari skor penilaian observasi kegiatan siswa, siswa mendapat skor 47 dari skor ideal 52. Sehingga persentase kinerja siswa adalah 90,4\%. Artinya siswa telah mencapai $90,4 \%$ dalam kinerjanya melakukan pembelajaran dengan menggunakan permainan monopoli digital. Persentase kinerja siswa dalam melaksanakan pembelajaran berada pada kriteria sangat tinggi. Hal ini menunjukkan penelitian tidak perlu untuk melanjutkan ke siklus berikutnnya.

\section{PEMBAHASAN}

Berdasarkan hasil observasi, pengisian angket, dan refleksi yang telah dilaksanakan selama siklus 1 dan siklus 2, pelajaran matematika dengan pokok bahasan menentukan pasangan bilangan yang hasil jumlah, selisih, hasil kali, dan hasil bagi yang sudah diketahui yang dilaksananakan dengan menerapkan permainan monopoli digital berdampak positif terhadap siswa kelas IIIA di SD Islam Sabilillah Malang yang berada di Kecamatan Blimbing, Kota Malang. Hal tersebut dibuktikan dengan adanya peningkatan baik dari segi proses pembelajaran maupun minat belajar siswa terhadap pelajaran matematika. Hasil yang diperoleh tersebut benar-benar sesuai dengan apa yang diharapkan oleh peneliti. Peningkatan skor minat dapat dilihat pada Tabel berikut ini.

\section{Tabel 6 Hasil skor minat belajar matematika pra siklus, siklus I, dan siklus II}

\begin{tabular}{cccc}
\hline \multicolumn{1}{c}{ Aspek yang diamati } & Nilai Pra siklus & Nilai siklus 1 & Nilai siklus 2 \\
\hline \multicolumn{1}{c}{ Nilai tertinggi } & 42 & 44 & 52 \\
\hline \multicolumn{1}{c}{ Nilai terendah } & 20 & 22 & 30 \\
\hline \multicolumn{1}{c}{ Nilai rata-rata } & 30,39 & 34,39 & 40,13 \\
\hline $\begin{array}{l}\text { Jumlah siswa yang telah } \\
\text { mencapai kriteria minat } \\
\text { sedang }\end{array}$ & 12 & 21 & 25 \\
\hline $\begin{array}{l}\text { Persentase siswa yang telah } \\
\text { minat sedang atau lebih }\end{array}$ & $38 \%$ & $68 \%$ & $81 \%$ \\
\hline
\end{tabular}

Minat belajar matematika siswa kelas III A di SD Islam Sabilillah Malang tergolong sangat rendah pada saat pra tindakan. Oleh karena itu, perlu adanya tindakan perbaikan yang harus segera dilakukan oleh guru untuk meningkatkan minat belajar matematika siswa yang masih rendah. Tindakan untuk meningkatkan minat belajar ini dilakukan untuk dapat meningkatkan keberhasilan siswa dalam mempelajari matematika. Hal ini sesuai dengan pendapat yang dikemukakan Mikarsa dkk (2007) bahwa minat merupakan salah satu faktor internal yang mempengaruhi belajar. Minat akan membantu keberhasilan siswa dalam belajar, dikarenakan belajar akan lebih berhasil jika sesuai dengan minat siswa. Peningkatan minat belajar matematika siswa disebabkan guru memanfaatkan permainan monopoli digital yang menyenangkan bagi siswa untuk melatih keterampilan siswa dalam menguasai materi operasi hitung bilangan cacah pada KD 3.3. Pernyataan tersebut menunjukkan salah satu kelebihan dari permainan yang dinyatakan Sadiman, dkk (2009), yaitu permainan merupakan hal yang menyenangkan dan menghibur sehingga dapat menarik perhatian dan minat siswa.

Peningkatan skor minat siswa pada siklus I yang belum memenuhi kriteria keberhasilan tindakan membuat peneliti melanjutkan penelitian ini masuk ke siklus II. Selama pembelajaran berlangsung, ada beberapa hal yang menjadi kekurangan dan perlu diperbaiki 
pada pembelajaran selanjutnya. Berdasarkan kendala utama yaitu kurangnya reward bagi siswa, maka guru perlu memberikan reward pada siswa melalui permainan tersebut. Dengan harapan, permainan yang disertai skor ini dapat lebih meningkatkan minat belajar siswa. Hal ini berdasarkan Tarigan (2017) yang menyatakan bahwa penggunaan metode reward and punishment dapat meningkatkan motivasi belajar siswa pada pembelajaran matematika khususnya materi pokok satuan panjang baku. Selain itu Agustina, Nurita (2012) juga menyimpulkan dalam penelitiannya bahwa penerapan metode reward and punishment dapat meningkatkan hasil belajar siswa SD pada mata pelajaran matematika.

Selain itu keterampilan membuat masalah atau soal matematika dan pemecahan masalah matematika juga terdapat pada media yang digunakan pada penelitian ini. Hal ini terdapat pada aturan permainan ini yaitu jika terdapat pemain yang menempati lokasi negara/kota, maka pemilik lokasi berhak memberikan soal kepada pemain tersebut. Jika pemain dapat mengerjakan dengan benar maka ia mendapat skor namun tidak ada pengurangan poin jika jawabannya salah. Selain itu jika ada jawaban pemain yang salah maka akan dikoreksi oleh anggota pemain yang lain sehingga terdapat proses membuat masalah dan memecahkan masalah secara bersama-sama. Pentingnya keterampilan membuat masalah ini didukung dengan penelitian yang dilakukan oleh Abu \& Elwan (2000) yang menunjukkan bahwa siswa yang mengikuti pembelajaran dengan strategi pembuatan soal (problem posing) mempunyai kemampuan yang lebih baik dalam memecahkan masalah. Hasil ini juga sesuai dengan penelitian yang dilakukan oleh Oktiana, dkk. (2010) yang salah satunya menunjukkan bahwa terdapat perbedaan kemampuan pemahaman konsep matematika antara siswa yang memperoleh pembelajaran problem posing dengan siswa yang memperoleh pembelajaran konvensional. Melalui multimedia interaktif ini siswa dapat melatih kemampuannya dalam memecahkan masalah (problem solving), membuat masalah matematika (problem posing) dan berkomunikasi aktif misalnya terdapat forum diskusi antar pemain dalam mengerjakan soal dari multimedia ini. Nugroho (2009) menyatakan bahwa Multimedia interaktif merupakan gabungan dari berbagai media, seperti teks, gambar, animasi, suara, video, yang disajikan melalui komputer multimedia, dan memiliki kemampuan untuk melibatkan atau berinteraksi dengan pengguna.

\section{SIMPULAN DAN SARAN}

Berdasarkan hasil penelitian dan pembahasan dapat disimpulkan bahwa penggunaan permainan monopoli digital dapat meningkatkan minat belajar matematika siswa kelas III A di SD Islam Sabilillah Malang pada materi operasi bilangan cacah. Hal tersebut dapat dilihat dari data penelitian yang menunjukkan bahwa sebelum diberi tindakan minat belajar matematika siswa masih rendah. Skor rata-rata angket minat belajar matematika siswa hanya sebesar 30,39 dan presentase siswa yang telah mencapai skor minat sedang hanya sebesar $38 \%$. Pada siklus I dikenai tindakan dengan sehingga skor rata-rata angket minat belajar matematika siswa meningkat menjadi 34,39 dan persentase siswa yang telah mencapai skor minat sedang menjadi $68 \%$. Pada siklus II dikenai tindakan dengan tetap menggunakan permainan monopoli digital, namun dilakukan beberapa modifikasi pada skenario yaitu aturan penskoran pada permainan, sebagai bentuk reward and punishment. Skor rata-rata angket minat belajar siswa menjadi 40,13 dan persentase siswa yang mencapai kriteria minat sedang telah mencapai kriteria keberhasilan yang ditentukan yaitu sebesar $81 \%$.

Berdasarkan paparan data dan pembahasan, peneliti menyarankan bahwa media pembelajaran ini dapat digunakan sebagai alternatif media pembelajaran untuk meningkatkan minat belajar pada materi dan soal-soal yang lain, dalam penelitian ini, kemampuan argumentasi siswa sudah muncul namun belum optimal, maka perlu dikembangkan dengan metode pembelajaran lain untuk meningkatkan kemampuan berkomunikasi siswa, peneliti 
juga memberikan rekomendasi kepada peneliti lain untuk mengembangkan multimedia monopoli digital ini agar lebih interaktif atau scenario permainan yang lebih menarik.

\section{DAFTAR RUJUKAN}

Abu-Elwan, R. (2000). The development of Mathematical Problem Posing Skills for Prospective Middle School Teachers. [online]. Tersedia: (http://dipmat.math.unipa.it/ grim/EAbu-elwan8.PDF. diakses 8 Mei 2019)

Agustina, N. (2012). Penerapan Reward dan Punishment sebagai Upaya Meningkatkan Hasil Belajar Siswa Kelas V Mata Pelajaran Matematika SDN 03 Nglebak Kecamatan Tawangmangu. Skripsi thesis, Universitas Muhammadiyah Surakarta.

Hasana, S.N. \& Maharany, E.R. (2017). Pengembangan Multimedia Menggunakan Visual Basic for Application (VBA) untuk Meningkatkan Profesionalisme Guru Matematika. Jurnal Pendidikan Matematika Universitas Islam Malang Vol. 3; Nomor 2, 2442 4668 (http://riset.unisma.ac.id/index.php/jpm/article/view/648 diakses 10 Februari 2019)

Hurlock, Elizabeth. (1980) . Psikologi Perkembangan: Suatu Pendekatan Sepanjang Rentang Kehidupan. (Alih bahasa: Istiwidayanti dan Soedjarwo). Jakarta: Erlangga.

Husna, A.M. (2009). 100+ Permainan Tradisional Indonesia: Untuk kreativitas,ketangkasan dan keakraban. Jakarta: Andi Publisher.

Mikarsa, H.L. dkk. (2007). Pendidikan Anak di SD. Jakarta: Universitas Terbuka.

Nugroho, A.H. (2009). Pengembangan Multimedia Pembelajaran Untuk Peningkatan Kualitas Pembelajaran Mata Kuliah Akuntansi. Widya Dharma Jurnal Kependidikan, Vol. 20. No.1, Oktober 2009

Nursit, I. (2016). Pengembangan Multimedia Interaktif Berbasis Power Point (MacroEnabled) Pada Mata Kuliah Geometri Euclid Dalam Pembelajaran Matematika. Jurnal Media Pendidikan Matematika "J-MPM" Vol. 4 No. 1, ISSN 2338-3836. (http://ojs.ikipmataram.ac.id/index.php/jmpm/article/view/127 diakses 1 Maret 2019)

Oktiana, dkk. (2010). Pengaruh Pembelajaran Problem Posing terhadap Kemampuan Pemahaman Konsep Matematika Peserta Didik Kelas XI IPA SMA Negeri 6 Palembang. Jurnal Pendidikan Matematika, 4. 70-80.

Pitadjeng. (2006). Pembelajaran Matematika yang Menyenangkan. Jakarta: Depdiknas.

Sadiman, A.S dkk. (2009). Media Pendidikan, Pengertian, Pengembangan,dan pemanfaatannya. Jakarta: Raja Grafindo Persada.

Susanto, A., Raharjo., Muji S. R. (2012). Permainan Monopoli sebagai Media Pembelajaran Sub Materi Sel pada Siswa SMA Kelas XI IPA. Jurnal Pendidikan Biologi Volume 1 No. 1 : Universitas Negeri Surabaya (http://ejournal.unesa.ac.id/index.php/bioedu diakses tanggal 20 Mei 2019).

Syah, Muhibbin. (2010). Psikologi Belajar. Jakarta : Rajawali Pers.

Tarigan, MR Pocky Ray Robby (2017). Penerapan Metode Reward and Punisment Untuk Meningkatkan Motivasi Belajar Siswa pada Mata Pelajaran Matematika Di Kelas IV SDN 101800 Delitua T.A 2016/2017. Undergraduate thesis, Universitas Negeri Medan. 